\title{
Investigating molecular mechanisms of insecticide resistance in the Eastern Democratic Republic of the Congo
}

Janvier Bandibabone ${ }^{1 \dagger}$, Charles McLoughlin ${ }^{2 \dagger}$, Sévérin N'Do ${ }^{3,6,8}$, Chimanuka Bantuzeko ${ }^{1,4}, V$ ital Byabushi ${ }^{5}$, Muhigwa Jeanberckmans ${ }^{4}$, Maite Guardiola ${ }^{3}$, Bertin Zawadi ${ }^{1}$, Abdoulaye Diabaté ${ }^{6}$, Jorian Prudhomme ${ }^{3,7}$, Thomas Walker ${ }^{2}$ and Louisa A. Messenger ${ }^{2^{*}}$

\begin{abstract}
Background: Malaria vector control in the Democratic Republic of the Congo is plagued by several major challenges, including inadequate infrastructure, lack of access to health care systems and preventative measures, and more recently the widespread emergence of insecticide resistance among Anopheles mosquitoes. Across 26 provinces, insecticide resistance has been reported from multiple sentinel sites. However, to date, investigation of molecular resistance mechanisms among Anopheles vector populations in DRC has been more limited.

Methods: Adult Anopheles gambiae sensu lato (s.I.) and Anopheles funestus s.I. were collected from two sites in SudKivu province and one site in Haut-Uélé province and PCR-screened for the presence of 11 resistance mutations, to provide additional information on frequency of resistance mechanisms in the eastern $\mathrm{DRC}$, and to critically evaluate the utility of these markers for prospective country-wide resistance monitoring.

Results: L1014F-kdr and L1014S-kdr were present in 75.9\% and 56.7\% of An. gambiae s.I. screened, respectively, with some individuals harbouring both resistant alleles. Across the three study sites, L43F-CYP4J5 allele frequency ranged from 0.42 to 0.52 , with evidence for ongoing selection. G119S-acel was also identified in all sites but at lower levels. A triple mutant haplotype (comprising the point mutation CYP6P4-I236M, the insertion of a partial Zanzibar-like transposable element and duplication of (YP6AA1) was present at high frequencies. In An. funestus s.l. cis-regulatory polymorphisms in CYP6P9a and CYP6P9b were detected, with allele frequencies ranging from 0.82 to 0.98 and 0.65 to 0.83 , respectively.
\end{abstract}

Conclusions: This study screened the most up-to-date panel of DNA-based resistance markers in An. gambiae s.l. and An. funestus s.l. from the eastern DRC, where resistance data is lacking. Several new candidate markers (CYP4J5, G119Sace1, the triple mutant, CYP6P9a and CYP6P9b) were identified, which are diagnostic of resistance to major insecticide classes, and warrant future, larger-scale monitoring in the DRC to inform vector control decisions by the National Malaria Control Programme.

\footnotetext{
*Correspondence: louisa.messenger@lshtm.ac.uk

†Janvier Bandibabone and Charles McLoughlin contributed equally to this work

${ }^{2}$ Department of Disease Control, Faculty of Infectious and Tropical Diseases, London School of Hygiene and Tropical Medicine, London, UK

Full list of author information is available at the end of the article
} original author(s) and the source, provide a link to the Creative Commons licence, and indicate if changes were made. The images or other third party material in this article are included in the article's Creative Commons licence, unless indicated otherwise in a credit line to the material. If material is not included in the article's Creative Commons licence and your intended use is not permitted by statutory regulation or exceeds the permitted use, you will need to obtain permission directly from the copyright holder. To view a copy of this licence, visit http://creativecommons.org/licenses/by/4.0/. The Creative Commons Public Domain Dedication waiver (http://creativeco mmons.org/publicdomain/zero/1.0/) applies to the data made available in this article, unless otherwise stated in a credit line to the data. 
Keywords: Anopheles gambiae, Anopheles funestus, Insecticide resistance, Plasmodium falciparum, Democratic Republic of the Congo, Target site mutation, Metabolic resistance, Insecticide resistance surveillance

\section{Background}

Malaria is a significant public health concern in the Democratic Republic of the Congo (DRC), where it is currently responsible for $12 \%$ and $11 \%$ of global malaria cases and deaths, respectively [1]. In the DRC, approximately $60 \%$ of the population reside in zones with an average Plasmodium falciparum prevalence above 50\% [2]; malaria is the leading cause of medical consultations, hospitalizations and death [3], accounting for $44 \%$ of all outpatient visits and $22 \%$ of deaths in children under 5 years old [4]. Malaria vector control in the DRC relies on universal coverage of insecticide-treated nets (ITNs), via mass campaigns, community-based top-ups to maintain high coverage, and continuous distributions through routine antenatal care (ANC) and child immunization services by the national expanded programme on immunization (EPI) [5]. Small-scale indoor residual spraying (IRS) is also undertaken by private enterprises (usually mining operations) in focal areas [5]. Between 2011 and 2018, an estimated 134.8 million pyrethroid-treated ITNs were distributed nationwide through such mechanisms [6]. However, recent estimates of net access and use across the country remain low, with the proportion of households with at least one ITN for every two people declining from $47 \%$ to $2013 / 14$ to $44 \%$ in $2017 / 18$, and the proportion of children under five years old reported sleeping under an ITN the previous night also decreasing from $56 \%$ to $2013 / 14$ to $51 \%$ in $2017 / 18$ [7].

Malaria control in the DRC is plagued by several major challenges, including poor transportation and communication infrastructure, a majority rural population, high poverty, political and socio-economic instability, lack of access to health care systems and preventative measures for at-risk populations, and more recently the widespread emergence of insecticide resistance among Anopheles vector populations. Across 26 provinces in the DRC, insecticide resistance in An. gambiae sensu lato (s.l.) and An. funestus s.l. has been reported from multiple sentinel sites [8], including reduced susceptibility to DDT, deltamethrin and permethrin in Kwilu [9], Nord-Ubangi [10] and SudKivu provinces [11], and to deltamethrin and DDT in Haut-Uélé province [12]. In Kinshasa, high intensity pyrethroid and organochlorine resistance has been observed, with An. gambiae populations displaying low mortality after $6 \mathrm{~h}$ of exposure to DDT and permethrin [13], and significant proportions of vectors are capable of surviving exposure to five and ten times the diagnostic doses of alpha-cypermethrin, deltamethrin and permethrin [14]. Importantly, nationwide Demographic and Health surveys (DHS) in the DRC indicate higher levels of protection with ITNs containing deltamethrin, compared to permethrin, suggesting a partial influence of insecticide resistance on vector control intervention efficacy [15]. By comparison to pyrethroids, resistance profiles to other insecticide classes (e.g. organophosphates and carbamates) have been less clearly established, restricting the ability of the national malaria control programme (NMCP) to make evidence-based decisions for resistance management.

To date, the investigation of insecticide resistance mechanisms among Anopheles vector populations in DRC has been limited (summarized in Additional file 1: Table S1). L1014F- and L1014S- $k d r$ mutations are found at variable frequencies in An. gambiae across the country, with the former predominating in western and central provinces (Additional file 1: Table S1); a proportion of individuals have also been documented harbouring both L1014F and L1014S alleles. N1575Y is present at very low prevalence in Nord-Ubangi province [10], while other commonly described mutations, such as G119Sace1, have not been detected in the DRC (Additional file 1: Table S1). Among local An. funestus, overexpression of key detoxification enzymes (including CYP6P9a, CYP6P9b, CYP6M7, CYP6P4a, CYP6P4b and GSTE2) has been identified in pyrethroid resistant field populations [12, 13] (Additional file 1: Table S1). Furthermore, increased mortality following pre-exposure of resistant An. gambiae to the synergist piperonyl butoxide (PBO) before pyrethroid bioassays, also indicates a role for metabolic resistance mechanisms in this species complex in the DRC $[8,10]$, supported by reports of overexpression of CYP6M2 and CYP6P1 [12].

While recent next-generation sequencing initiatives have characterised substantial genetic diversity within natural Anopheles populations, concerns have been raised for the rapid evolution and spread of novel insecticide resistance mechanisms [16, 17]. However, real-time tracking of resistance mechanisms in the field, especially the identification of diagnostic markers that are predictive of vector control intervention failure [18, 19], is still lacking. As an intermediate step for future insecticide resistance monitoring efforts in the DRC, this study assessed $P$. falciparum infection prevalence and the frequency of 11 published insecticide resistance mutations 
among populations of An. gambiae s.l. and An. funestus s.l., collected from three areas of pyrethroid resistance in the eastern DRC.

\section{Methods}

Mosquito collections and species identification

Adult Anopheles were collected from households in two sites in Sud-Kivu province (Tchonka; $2^{\circ} 19^{\prime} 18^{\prime \prime} \mathrm{S}$, $27^{\circ} 32^{\prime} 24^{\prime \prime} \mathrm{E}$ and Tushunguti; $1^{\circ} 48^{\prime} 19^{\prime \prime} \mathrm{S}, 28^{\circ} 45^{\prime} 00.5^{\prime \prime} \mathrm{E}$ ) and one site in Haut-Uélé province (Kibali; $3^{\circ} 6^{\prime} 59^{\prime \prime} \mathrm{N}$, $29^{\circ} 35^{\prime} 8^{\prime \prime} \mathrm{E}$ ) using Centers for Disease Control (CDC) light traps during the rainy season in Tchonka (100 houses: April-June 2018), Tushunguti (50 houses: December 2017-February 2018) and Kibali (25 houses: June 2019) (Fig. 1). Mosquitoes were identified morphologically as members of the An. gambiae s.l. or An. funestus s.l. complexes [20].

Individual mosquitoes were homogenized in a Qiagen TissueLyser II with sterilized $5 \mathrm{~mm}$ stainless steel beads for $5 \mathrm{~min}$ at $30 \mathrm{~Hz}$ and incubated overnight at $56^{\circ} \mathrm{C}$. DNA was extracted using a Qiagen DNeasy 96 blood and tissue kit (Qiagen, UK), according to the manufacturer's protocol. A subset of mosquitoes, morphologically classified as An. gambiae s.l. $(\mathrm{n}=24)$ or An. funestus s.l. $(\mathrm{n}=16)$, were further identified to species-level by PCR [21, 22]. A total of 163 An. funestus s.l. from Tchonka $(\mathrm{n}=133)$ and Tushunguti $(\mathrm{n}=30)$ and 192 An. gambiae s.l. from Tchonka $(n=131)$, Tushunguti $(n=32)$ and Kibali $(n=29)$ were used for insecticide resistance mutation analyses.

\section{Plasmodium falciparum screening}

Individual mosquitoes $(\mathrm{n}=355)$ were screened for the presence of $P$. falciparum using a SYBR green real-time assay targeting the parasite cytochrome c oxidase subunit 1 (cox1) mitochondrial gene (present in all stages of the $P$. falciparum life cycle) [23].

\section{Anopheles gambiae s.l. target site mutation screening}

Mosquito individuals morphologically identified as $A n$. gambiae s.l. $(\mathrm{n}=192)$ were screened for eight mutations: L1014S-kdr, L1014F- $k d r$, G119S-ace1, N1575Y, L43FCYP4J5, CYP6P4 (I236M), Zanzibar-like transposable element (TE) and CYP6AA1 duplication.

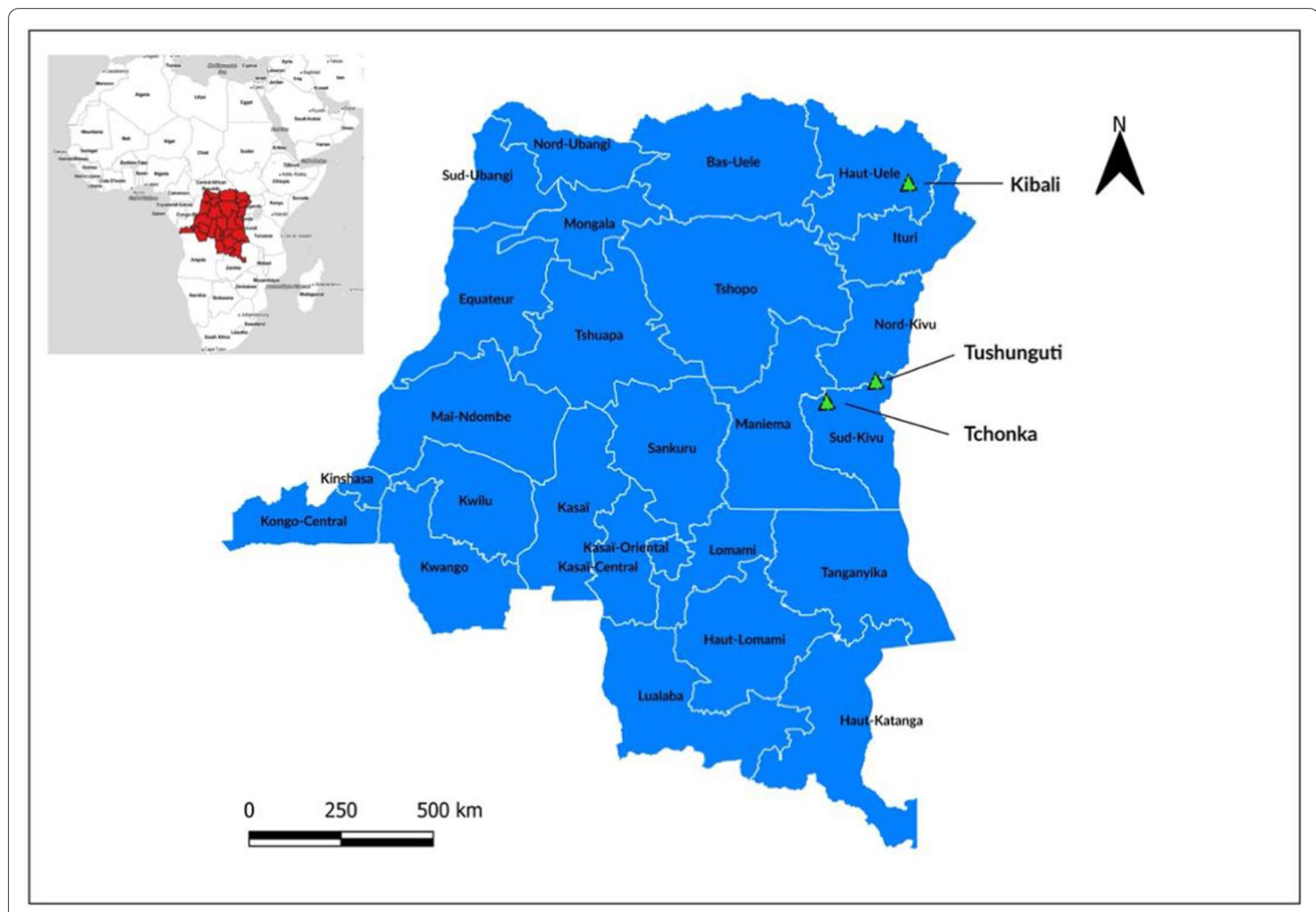

Fig. 1 Map of study sites in Sud-Kivu (Tchonka, and Tushunguti) and Haut-Uélé (Kibali) provinces, in the Democratic Republic of the Congo 
Table 1 PCR primers, probes and reaction conditions

\begin{tabular}{|c|c|c|c|c|c|}
\hline & $\begin{array}{l}\text { Primers and probes } \\
\text { (concentrations) }\end{array}$ & $5^{\prime}$ modifications & Sequences & Reaction conditions & References \\
\hline \multicolumn{6}{|l|}{ An. gambiae s.l. mutation } \\
\hline L1014F-kdr & $\begin{array}{l}\text { IPCF }(2.5 \mathrm{pmol} / \mu \mathrm{L}) \\
\text { AltRev }(2.5 \mathrm{pmol} / \mu \mathrm{L}) \\
\text { WT }(25 \mathrm{pmol} / \mu \mathrm{L}) \\
\text { West }(8 \mathrm{pmol} / \mu \mathrm{L})\end{array}$ & & $\begin{array}{l}\text { GATAATGTGGATAGATTCCCCGAC } \\
\text { CATG } \\
\text { TGCCGTTGGTGCAGACAAGGATG } \\
\text { GGTCCATGTTAATTTGCATTACTTACG } \\
\text { AATA } \\
\text { CTTGGCCACTGTAGTGATAGGAAA } \\
\text { TGTT }\end{array}$ & $\begin{array}{l}1 \text { cycle: } 5 \text { min at } 95^{\circ} \mathrm{C} \\
35 \text { cycles: } 30 \text { s at } 95^{\circ} \mathrm{C}, \\
30 \text { s at } 59^{\circ} \mathrm{C}, 30 \text { s at } 72^{\circ} \mathrm{C} \\
1 \text { cycle: } 5 \text { min at } 72^{\circ} \mathrm{C}\end{array}$ & [25] \\
\hline L1014S-kdr & $\begin{array}{l}\text { IPCF }(2.5 \mathrm{pmol} / \mu \mathrm{L}) \\
\text { AltRev }(2.5 \mathrm{pmol} / \mu \mathrm{L}) \\
\text { WT }(5 \mathrm{pmol} / \mu \mathrm{L}) \\
\text { East }(2.5 \mathrm{pmol} / \mu \mathrm{L})\end{array}$ & & $\begin{array}{l}\text { GATAATGTGGATAGATTCCCCGAC } \\
\text { CATG } \\
\text { TGCCGTTGGTGCAGACAAGGATG } \\
\text { GGTCCATGTTAATTTGCATTACTTACG } \\
\text { AATA } \\
\text { CTTGGCCACTGTAGTGATAGGAAAATC }\end{array}$ & $\begin{array}{l}1 \text { cycle: } 5 \text { min at } 95^{\circ} \mathrm{C} \\
35 \text { cycles: } 30 \text { s at } 95^{\circ} \mathrm{C}, \\
30 \text { s at } 57^{\circ} \mathrm{C}, 30 \text { s at } 72^{\circ} \mathrm{C} \\
1 \text { cycle: } 5 \text { min at } 72^{\circ} \mathrm{C}\end{array}$ & [25] \\
\hline N1575Y & $\begin{array}{l}\text { Forward }(1 \mu \mathrm{M}) \\
\text { Reverse }(1 \mu \mathrm{M}) \\
\mathrm{N}(0.5 \mu \mathrm{M}) \\
\mathrm{Y}(0.5 \mu \mathrm{M})\end{array}$ & $\begin{array}{l}\text { HEX } \\
\text { FAM }\end{array}$ & $\begin{array}{l}\text { TGGATCGCTAGAAATGTTCATGACA } \\
\text { CGAGGAATTGCCTTTAGAGGTTTCT } \\
\text { ATTTTTTTCATTGCATTATAGTAC } \\
\text { TTTTTCATTGCATAATAGTAC }\end{array}$ & $\begin{array}{l}1 \text { cycle: } 15 \text { min at } 95^{\circ} \mathrm{C} \\
40 \text { cycles: } 15 \mathrm{~s} \text { at } 94^{\circ} \mathrm{C}, \\
1 \text { min at } 60^{\circ} \mathrm{C}\end{array}$ & [24] \\
\hline G119S-ace1 & $\begin{array}{l}\text { Forward }(0.8 \mu \mathrm{M}) \\
\text { Reverse }(0.8 \mu \mathrm{M}) \\
\mathrm{G}(0.2 \mu \mathrm{M}) \\
\mathrm{S}(0.2 \mu \mathrm{M})\end{array}$ & $\begin{array}{l}\text { HEX } \\
\text { FAM }\end{array}$ & $\begin{array}{l}\text { GGCCGTCATGCTGTGGAT } \\
\text { GCGGTGCCGGAGTAGA } \\
\text { TTCGGCGGCGGCT } \\
\text { TTCGGCGGCAGCT }\end{array}$ & $\begin{array}{l}1 \text { cycle: } 10 \text { min at } 95^{\circ} \mathrm{C} \\
40 \text { cycles: } 10 \text { s at } 95^{\circ} \mathrm{C}, \\
35 \text { s at } 60^{\circ} \mathrm{C}\end{array}$ & [25] \\
\hline L43F-CYP4J5 & $\begin{array}{l}\text { Forward }(1 \mu \mathrm{M}) \\
\text { Reverse }(1 \mu \mathrm{M}) \\
\text { Probe } 1(0.5 \mu \mathrm{M}) \\
\text { Probe } 2(0.5 \mu \mathrm{M})\end{array}$ & $\begin{array}{l}\text { FAM } \\
\text { HEX }\end{array}$ & $\begin{array}{l}\text { AGCCTGCGCGTGTGATA } \\
\text { CTTCTTCTCCTGTGGTTCGTTTG } \\
\text { TTGCCGGAAGGCAGT } \\
\text { TTGCCGGAGGGCAGT }\end{array}$ & $\begin{array}{l}1 \text { cycle: } 10 \text { min at } 95^{\circ} \mathrm{C} \\
40 \text { cycles: } 15 \mathrm{~s} \text { at } 92^{\circ} \mathrm{C}, \\
1 \text { min at } 60^{\circ} \mathrm{C}\end{array}$ & [26] \\
\hline CYP6P4-I236M & $\begin{array}{l}\text { CYP6P4_I236M_Forward } \\
(0.35 \mu \mathrm{M}) \\
\text { CYP6P4_I236M_Reverse } \\
(0.35 \mu \mathrm{M}) \\
\text { CYP6P4_I-Wild }(0.2 \mu \mathrm{M}) \\
\text { CYP6P4_M-Mutant }(0.2 \\
\mu \mathrm{M})\end{array}$ & $\begin{array}{l}\text { FAM } \\
\text { HEX }\end{array}$ & $\begin{array}{l}\text { AGTTTATGTTTGCGACCACGTT } \\
\text { TCCACCGTCTCGCGCACAAC } \\
\text { TTC+ATGC+C+G+ATGC } \\
\text { TTC+ATGC+C+C+ATGC }\end{array}$ & $\begin{array}{l}1 \text { cycle: } 3 \text { min at } 95^{\circ} \mathrm{C} \\
20 \text { cycles: } 15 \text { s at } 95^{\circ} \mathrm{C}, \\
30 \text { s at } 66^{\circ} \mathrm{C} \\
23 \text { cycles: } 10 \text { s at } 95^{\circ} \mathrm{C}, \\
20 \text { s at } 58^{\circ} \mathrm{C}, 11 \text { s at } 72^{\circ} \mathrm{C}\end{array}$ & {$[27]$} \\
\hline Zanzibar-like TE & $\begin{array}{l}\text { ZZB_Flank_A }(0.35 \mu \mathrm{M}) \\
\text { ZZB_Flank_B }(0.35 \mu \mathrm{M}) \\
\text { ZZB_Int_A }(0.35 \mu \mathrm{M}) \\
\text { ZZB_Mutant }(0.2 \mu \mathrm{M}) \\
\text { ZZB_WT }(0.2 \mu \mathrm{M})\end{array}$ & $\begin{array}{l}\text { FAM } \\
\text { HEX }\end{array}$ & $\begin{array}{l}\text { CAAAATCAATGKCACRGAGC } \\
\text { CGCTACAATGAAKGGAAAGTC } \\
\text { CATTACATGGCGACCGTACCT } \\
\text { A+C+ATTA+CA+CTTTGT+CA+GTA } \\
\text { GATG+TT+CTTTK+T+CA+G+TATT }\end{array}$ & $\begin{array}{l}1 \text { cycle: } 3 \text { min at } 95^{\circ} \mathrm{C} \\
40 \text { cycles: } 10 \text { s at } 95^{\circ} \mathrm{C} \\
20 \text { s at } 58^{\circ} \mathrm{C}, 11 \text { s at } 72^{\circ} \mathrm{C}\end{array}$ & {$[27]$} \\
\hline CYP6AA1 duplication & $\begin{array}{l}\text { AA1_Dup1_ins1 (0.35 } \\
\mu M) \\
\text { AA1_Dup1_outs }(0.35 \\
\mu M) \\
\text { AA1_Dup1_ins2 }(0.35 \\
\mu M) \\
\text { AA1_Dup1_outs }(0.2 \mu M) \\
\text { AA1_Dup1_ins }(0.2 \mu M) \\
\text { AA1_Dup1_junct }(0.2 \\
\mu M)\end{array}$ & $\begin{array}{l}\text { Cy5 } \\
\text { HEX } \\
\text { FAM }\end{array}$ & $\begin{array}{l}\text { CAGTGCGGTACGCTCGTTAA } \\
\text { GGATCGGTTTACAGCGGACG } \\
\text { CATCACCTGTGCTCGCAARTT } \\
\text { CCAT+CA+C+CGAA+CG } \\
\text { AGAA+CCTGCA+C+CAA } \\
\text { A+CA+AT+TAATT+G+CAT+CGG }\end{array}$ & $\begin{array}{l}1 \text { cycle: } 3 \text { min at } 95^{\circ} \mathrm{C} \\
40 \text { cycles: } 10 \text { s at } 95^{\circ} \mathrm{C} \\
20 \text { s at } 57^{\circ} \mathrm{C}, 15 \text { s at } 72^{\circ} \mathrm{C}\end{array}$ & {$[27]$} \\
\hline 2La inversion & $\begin{array}{l}23 \mathrm{~A} 2(25 \mathrm{pmol} / \mu \mathrm{L}) \\
27 \mathrm{~A} 2(25 \mathrm{pmol} / \mu \mathrm{LL}) \\
\text { DPCross } 52 \mathrm{~L}+(25 \mathrm{pmol} / \\
\mu \mathrm{L})\end{array}$ & & $\begin{array}{l}\text { CTCGAAGGGACAGCGAATTA } \\
\text { ACACATGCTCCTTGTGAACG } \\
\text { GGTATTTCTGGTCACTCTGTTGG }\end{array}$ & $\begin{array}{l}1 \text { cycle: } 2 \text { min at } 94^{\circ} \mathrm{C} \\
35 \text { cycles: } 30 \text { s at } 94^{\circ} \mathrm{C}, \\
30 \text { s at } 60^{\circ} \mathrm{C}, 45 \text { s at } 72^{\circ} \mathrm{C} \\
1 \text { cycle: } 10 \text { min at } 72^{\circ} \mathrm{C}\end{array}$ & {$[25]$} \\
\hline \multicolumn{6}{|l|}{ An. funestus s.l. mutation } \\
\hline L119F-GSTe2 & $\begin{array}{l}\text { Forward }(1 \mu \mathrm{M}) \\
\text { Reverse }(1 \mu \mathrm{M}) \\
\text { L119 }(0.5 \mu \mathrm{M}) \\
119 \mathrm{~F}(0.5 \mu \mathrm{M})\end{array}$ & $\begin{array}{l}\text { HEX } \\
\text { FAM }\end{array}$ & $\begin{array}{l}\text { AACAATTTTTCATTTCTTATTCTCATT } \\
\text { TAC } \\
\text { CGACTCGATCTTCGGGAATGTC } \\
\text { AGGAGCGTATTCTTTTCTAC } \\
\text { AGGAGCGTATTTTTTTCTA }\end{array}$ & $\begin{array}{l}1 \text { cycle: } 10 \text { min at } 95^{\circ} \mathrm{C} \\
40 \text { cycles: } 15 \mathrm{~s} \text { at } 92^{\circ} \mathrm{C} \\
\text { and } 1 \text { min at } 60^{\circ} \mathrm{C}\end{array}$ & {$[28]$} \\
\hline
\end{tabular}


Table 1 (continued)

\begin{tabular}{|c|c|c|c|c|c|}
\hline & $\begin{array}{l}\text { Primers and probes } \\
\text { (concentrations) }\end{array}$ & $5^{\prime}$ modifications & Sequences & Reaction conditions & References \\
\hline CYP6P9a & $\begin{array}{l}\text { Forward }(1 \mu \mathrm{M}) \\
\text { Reverse }(1 \mu \mathrm{M})\end{array}$ & & $\begin{array}{l}\text { TCCCGAAATACAGCCTTTCAG } \\
\text { ATTGGTGCCATCGCTAGAAG }\end{array}$ & $\begin{array}{l}1 \text { cycle: } 95^{\circ} \mathrm{C} \text { for } 3 \mathrm{~min} \\
40 \text { cycles: } 94^{\circ} \mathrm{C} \text { for } 30 \mathrm{~s} \text {, } \\
55^{\circ} \mathrm{C} \text { for } 30 \mathrm{~s}, 72{ }^{\circ} \mathrm{C} \text { for } \\
1 \text { min } \\
1 \text { cycle: } 72^{\circ} \mathrm{C} \text { for } 10 \mathrm{~min}\end{array}$ & [18] \\
\hline CYP6P9b & $\begin{array}{l}\text { Forward }(1 \mu \mathrm{M}) \\
\text { Reverse }(1 \mu \mathrm{M})\end{array}$ & & $\begin{array}{l}\text { CCCCCACAGGTGGTAACTATCTGAA } \\
\text { TTATCCGTAACTCAATAGCGATG }\end{array}$ & $\begin{array}{l}1 \text { cycle: } 95^{\circ} \mathrm{C} \text { for } 3 \text { min } \\
40 \text { cycles: } 94^{\circ} \mathrm{C} \text { for } 30 \mathrm{~s} \text {, } \\
58^{\circ} \mathrm{C} \text { for } 30 \mathrm{~s}, 72{ }^{\circ} \mathrm{C} \text { for } \\
1 \mathrm{~min} \\
1 \text { cycle: } 72^{\circ} \mathrm{C} \text { for } 10 \mathrm{~min}\end{array}$ & [19] \\
\hline
\end{tabular}

PCR reaction primers, probes and conditions for all assays are detailed in Table 1.

For L1014F- $k d r$, amplifications were performed in $25 \mu \mathrm{L}$ reactions containing $2 \mu \mathrm{L}$ template DNA, $1 \mu \mathrm{L}$ IPCF, $1 \mu \mathrm{L}$ AltRev, $1 \mu \mathrm{L}$ WT, $3 \mu \mathrm{L}$ West, $4.5 \mu \mathrm{L} \mathrm{H}_{2} \mathrm{O}$, and $12.5 \mu \mathrm{L} 2 \times$ Hot Start Taq PCR Master Mix (New England Biolabs, UK). For L1014S-kdr, amplifications were performed in $25 \mu \mathrm{L}$ reactions containing $2 \mu \mathrm{L}$ template DNA, $2 \mu \mathrm{L}$ IPCF, $2 \mu \mathrm{L}$ AltRev, $2 \mu \mathrm{L}$ WT, $2 \mu \mathrm{L}$ East, 2.5 $\mu \mathrm{L} \mathrm{H}_{2} \mathrm{O}$, and $12.5 \mu \mathrm{L} 2 \times$ Hot Start Taq PCR Master Mix (New England Biolabs, UK). PCR products were separated in $2 \% \mathrm{E}-\mathrm{Gel}^{\mathrm{TM}}$ agarose gels with SYBR Safe (Invitrogen, UK). A control band at 314 base pairs (bp) indicated a successful reaction, a band at $214 \mathrm{bp}$ indicated the susceptible wild type allele, and a band at 156 bp indicated the resistant allele. No template controls (NTCs) were run in parallel for all assays.

For N1575Y, PCR reactions were prepared with $10 \mu \mathrm{L}$ of $2 \times$ QuantiTect $^{\mathrm{TM}}$ Probe PCR master mix (Qiagen, UK), the primers and probes listed in Table 1 , and $2 \mu \mathrm{L}$ template DNA for a final reaction volume of $20 \mu \mathrm{L}$ [24]. Positive controls from gDNA extracted from known $A n$. gambiae sensu stricto (s.s.) with and without the N1575Y mutation were included in each run, alongside NTCs.

For G119S-ace1, PCR reactions were prepared with 5 $\mu \mathrm{L} 2 \times$ PrimeTime $^{\circledR}$ Gene Expression Master Mix (Integrated DNA Technologies, UK), the primers and probes listed in Table 1 , and $2 \mu \mathrm{L}$ template DNA for a final reaction volume of $10 \mu \mathrm{L}$ [25]. Positive controls from gDNA extracted from known An. gambiae s.s. with and without the G119S-ace1 mutation were included in each run, alongside NTCs.

For L43F-CYP4J5, PCR reactions were prepared with $10 \mu \mathrm{L}$ of $2 \times$ QuantiTect $^{\mathrm{TM}}$ Probe PCR master mix (Qiagen, UK), the primers and probes listed in Table 1 , and $2 \mu \mathrm{L}$ template DNA for a final reaction volume of $20 \mu \mathrm{L}$ [26].

Three recently designed, independent, locked-nucleic acid (LNA) probe-based PCR assays were used to genotype the point mutation CYP6P4-I236M, the insertion of the partial Zanzibar-like TE and the duplication of CYP6AA1 [27]. For each assay, PCR reactions were prepared with $5 \mu \mathrm{L} 2 \times$ PrimeTime $^{\circledR}$ Gene Expression Master Mix (Integrated DNA Technologies, UK), the primers and probes listed in Table 1 , and $2 \mu \mathrm{L}$ template DNA for a final reaction volume of $10 \mu \mathrm{L}$.

For the 2La inversion region in An. gambiae s.l. which contains L43F-CYP4J5 [26], amplifications were performed in $25 \mu \mathrm{L}$ reactions containing $12.5 \mu \mathrm{L} 2 \times$ Hot Start Taq PCR Master Mix (New England Biolabs, UK), the primers listed in Table 1 , and $2 \mu \mathrm{L}$ template DNA

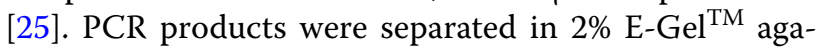
rose gels with SYBR Safe (Invitrogen, UK). A band at $492 \mathrm{bp}$ or $207 \mathrm{bp}$ indicated the $2 \mathrm{La}$ or $2 \mathrm{~L}+{ }^{\mathrm{a}}$ arrangement, respectively.

\section{Anopheles funestus s.l. target site mutation screening}

Mosquito individuals morphologically identified as $A n$. funestus s.l. $(\mathrm{n}=163)$ were screened for three metabolic mutations: L119F-GSTe2, CYP6P9a and CYP6P9b.

For L119F-GSTe2, PCR reactions were prepared with $10 \mu \mathrm{L}$ of $2 \times$ QuantiTect $^{\mathrm{TM}}$ Probe PCR master mix (Qiagen, UK), the primers and probes listed in Table 1 , and $2 \mu \mathrm{L}$ template DNA for a final reaction volume of $20 \mu \mathrm{L}$ [28].

For CYP6P9a, PCR reactions were performed in a final volume of $25 \mu \mathrm{L}$, containing $2 \times$ Hot Start Taq PCR Master Mix (New England Biolabs, UK), the primers listed in Table 1, and $2 \mu \mathrm{L}$ template DNA [18]. Ten microlitres of each PCR product were digested by adding $1 \mu \mathrm{L} 10 \times$ buffer TaqI, $0.2 \mu \mathrm{L}$ TaqI restriction enzyme (Thermo Scientific, UK) and $3.8 \mu \mathrm{L}$ of $\mathrm{H}_{2} \mathrm{O}$. Digests were incubated at $65{ }^{\circ} \mathrm{C}$ for $4 \mathrm{~h}$. Digested products were separated in $2 \%$ E-Gel ${ }^{\mathrm{TM}}$ agarose gels with SYBR Safe (Invitrogen, UK). A band at $450 \mathrm{bp}$ indicated the susceptible wild type allele, a band at $350 \mathrm{bp}$ and $100 \mathrm{bp}$ indicated the resistant allele.

For CYP6P9b, PCR reactions were performed in a final volume of $25 \mu \mathrm{L}$, containing $2 \times$ Hot Start Taq 
PCR Master Mix (New England Biolabs, UK), the primers listed in Table 1, and $2 \mu \mathrm{L}$ template DNA [19]. Ten microlitres of each $\mathrm{PCR}$ product were digested by adding $1 \mu \mathrm{L}$ CutSmart buffer, $0.2 \mu \mathrm{L}$ Tsp45I restriction enzyme (New England Biolabs, UK) and $3.8 \mu \mathrm{L}$ of $\mathrm{H}_{2} \mathrm{O}$. Digests were incubated at $65{ }^{\circ} \mathrm{C}$ for $4 \mathrm{~h}$. Digested products were separated in $2 \% \mathrm{E}^{-\mathrm{Gel}^{\mathrm{TM}}}$ agarose gels with SYBR Safe (Invitrogen, UK). A band at $550 \mathrm{bp}$ indicated the resistant allele and two bands at $400 \mathrm{bp}$ and $150 \mathrm{bp}$ indicated the susceptible wild type allele.

For both CYP6P9a $(n=8)$ and CYP6P9b $(n=8)$, PCRRFLP results for a subset of resistant and susceptible individuals were confirmed by sequencing as previously described [29]. In brief, PCR products used in the enzyme digests were submitted to Source BioScience (Source BioScience Plc, Nottingham, UK) for PCR reaction clean-up, followed by chain termination sequencing. Sequencing analysis was conducted in Geneious Prime ${ }^{\circledR}$ 2021.1.1.

\section{Data analysis}

Stratagene MxPro qPCR software (Agilent Technologies, UK) was used to produce standard curves for genotypic analysis. All statistical analyses were conducted in Stata/SE 17.0, including Pearson's Chi-squared test to investigate deviations from Hardy-Weinberg equilibrium and associations between study site, presence/ absence of resistance mutation and $P$. falciparum infection prevalence. Analysis of the triple LNA PCR assay to detect the point mutation CYP6P4-I236M, the insertion of the partial Zanzibar-like TE and the duplication of CYP6AA1, was conducted according to Njoroge et al. [27]. Heterozygotes and homozygotes for the CYP6AA1 duplication were differentiated by analysis of the ratio of the HEX, FAM and Cy5 Ct values: 2*Cy5-(FAM+HEX); ratio values were then arranged in ascending order, plotted on a line graph and heterozygotes and homozygotes differentiated by a change in the line gradient.

\section{Results}

Mosquito species identification and $P$. falciparum screening A subset of eight individual An. gambiae s.l. each from Tchonka, Tushunguti and Kibali and An. funestus s.l. from Tchonka and Tushunguti were identified to specieslevel by PCR; all were determined to be $A n$. gambiae s.s. (24/24) and An. funestus s.s. (16/16), respectively. $P$. falciparum infection rate (indicative of any parasite lifecycle stage) was $11.04 \%$ (18/163) and $10.94 \%$ (21/192) among An. funestus s.l. and An. gambiae s.l., respectively. By study site, $P$. falciparum infection rate for An. funestus s.l. was not significantly different between Tchonka $(12.03 \% ; 16 / 133)$ and Tushunguti $(6.7 \% ; 2 / 30)\left(x^{2}=0.717\right.$, $p=0.397)$, nor for An. gambiae s.l. $(13.0 \%$; $17 / 131$ in
Tchonka, 6.25\%; $2 / 32$ in Tushunguti and $6.9 \% ; 2 / 29$ in Kibali; $\left.\chi^{2}=1.77, p=0.413\right)$.

\section{Anopheles gambiae s.l. target site mutation screening}

Mosquito individuals morphologically identified as $A n$. gambiae s.l. were screened for the presence of eight mutations (Tables 2 and 3). L1014F- $k d r$ was present in $75.9 \%(142 / 187)$ of An. gambiae s.l. screened; 50\% (71/142) were homozygous L1014F/L1014F and 50\% were heterozygous L1014F/L1014S (Table 2). L1014S$k d r$ was present in 56.7\% (106/187) of An. gambiae s.l. tested; 33.0\% (35/106) were homozygous L1014S/L1014S and $67.0 \%(71 / 106)$ were heterozygous L1014F/L1014S (Table 2). No individuals were heterozygous for either L1014F or L1014S mutation alone. By study site there was a clear predominance of L1014F/L1014F (52.4\%; 66/126) and L1014F/L1014S (44.4\%; 56/126) in Tchonka, and L1014S/L1014S in Kibali (75.9\%; 22/29) (Table 2). In Kibali, there was evidence for selection acting on this locus $\left(\mathrm{X}^{2}=22.86, p<0.0001\right)$. N1575Y was not detected in any individual tested (190/190).

L43F-CYP4J5 was identified in 83.9\% (156/186) of $A n$. gambiae s.l. tested; $3.8 \%$ (6/156) were homozygous and $96.2 \%(150 / 156)$ were heterozygous (Table 3). Across the three study sites, L43F-CYP4J5 allele frequency ranged from 0.42 to 0.52 , with evidence for significant deviations from Hardy-Weinberg equilibrium $\left(x^{2}=38.26\right.$, 28.24 and 15.75 for Tchonka, Tushunguti and Kibali, respectively; $p<0.0001$ for all). Overall, $91.8 \%(168 / 183)$ of An. gambiae s.l. tested harboured the $2 \mathrm{~L}+{ }^{\mathrm{a}}$ inversion; $42.1 \%(77 / 183)$ were $2 \mathrm{~L}+{ }^{\mathrm{a}} /+^{\mathrm{a}}$ homozygous and $49.7 \%$ $(91 / 183)$ were $2 \mathrm{La}+{ }^{\mathrm{a}}$ heterozygous (Table 4$)$. Across the three study sites, evidence for ongoing selection for the 2La inversion was observed in Tchonka only $\left(x^{2}=15.24\right.$, $p<0.0001$ ).

G119S-ace1 was detected in 30.9\% (59/191) of An. gambiae s.l. tested; $3.4 \%(2 / 59)$ were homozygous and 96.6\% (57/59) were heterozygous (Table 3). There was no evidence for ongoing selection for G119S-ace1 in any study site, with the resistant allele frequency ranging from 0.11 to 0.19 (Table 3).

For An. gambiae s.l., there was no significant association with presence of any resistant allele and P. falciparum infection for L1014F- $k d r \quad\left(\chi^{2}=1.15, p=0.283\right)$, L1014S- $k d r \quad\left(\chi^{2}=1.75, \quad p=0.186\right), \quad$ L43F-CYP4J5 $\left(\mathrm{X}^{2}=1.30, p=0.254\right)$ or G119S-ace1 $\left(\mathrm{\chi}^{2}=3.05, p=0.081\right)$; nor $2 \mathrm{~L}^{+\mathrm{a}}$ inversion and $P$. falciparum infection $\left(\mathrm{x}^{2}=0.32\right.$, $p=0.573$ ).

The triple LNA PCR assay, used to genotype the point mutation CYP6P4-I236M, the insertion of the partial Zanzibar-like TE and the duplication of CYP6AA1, identified high frequencies of the triple homozygote mutant in all study sites (Table 5). Furthermore, the double 


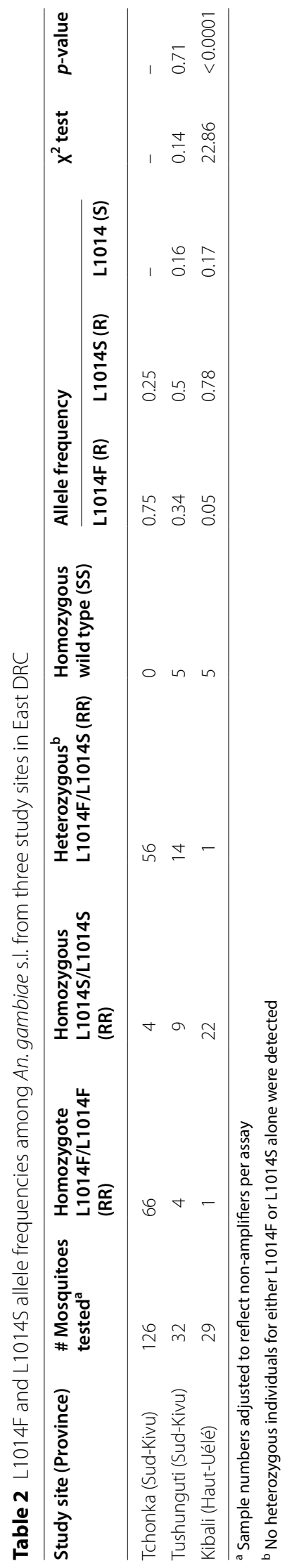




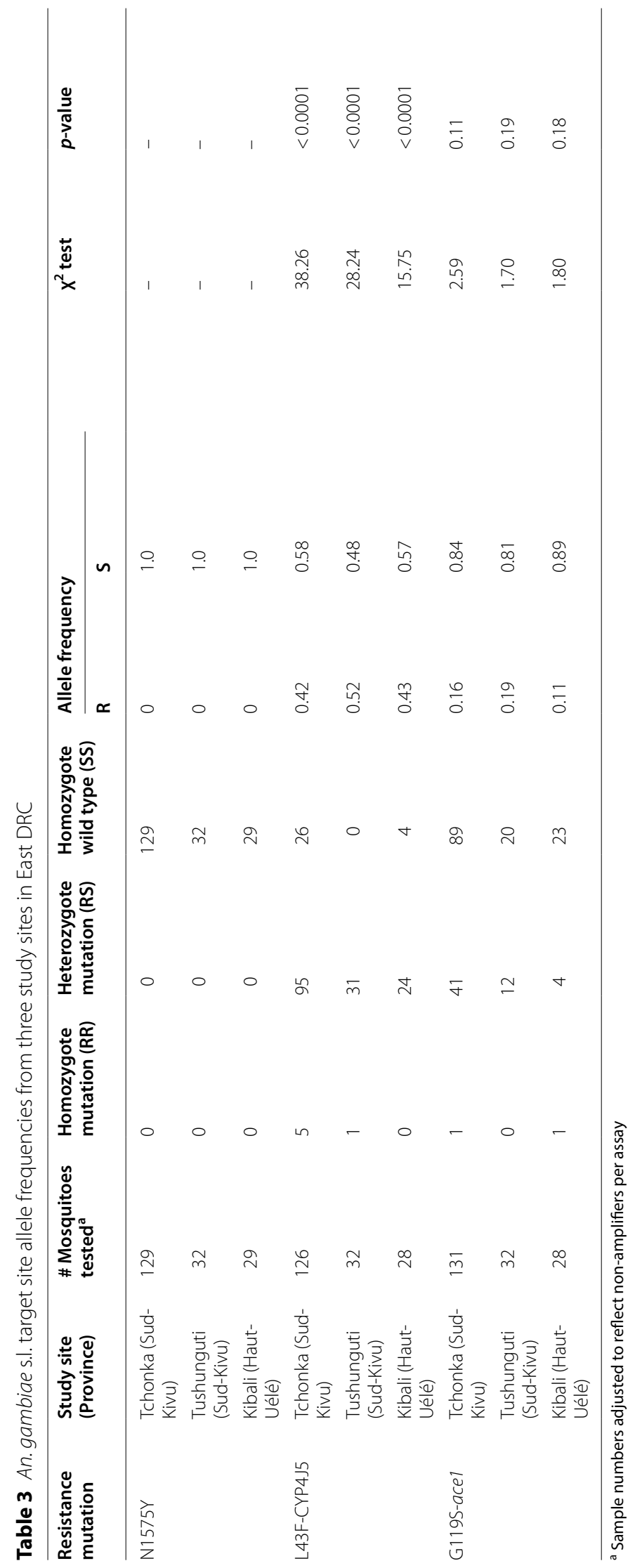


Table 4 An. gambiae s.l. 2La karyotypes from three study sites in East DRC

\begin{tabular}{|c|c|c|c|c|c|c|}
\hline Study site (Province) & $\begin{array}{l}\text { \# Mosquitoes } \\
\text { tested }^{\mathrm{a}}\end{array}$ & 2La/a & $2 \mathrm{La}+{ }^{\mathrm{a}}$ hybrid & $2 \mathrm{~L}++^{\mathrm{a}} /+^{\mathrm{a}}$ & $x^{2}$ test & $p$-value \\
\hline Tchonka (Sud-Kivu) & 125 & 1 & 68 & 56 & 15.24 & $<0.0001$ \\
\hline Tushunguti (Sud-Kivu) & 30 & 9 & 10 & 11 & 3.27 & 0.07 \\
\hline Kibali (Haut-Uélé) & 28 & 5 & 13 & 10 & 0.05 & 0.83 \\
\hline
\end{tabular}

a Sample numbers adjusted to reflect non-amplifiers per assay

Table 5 An. gambiae s.I. triple mutant genotype (CYP6P4-I236M-Zanzibar-like TE-CYP6AA1 duplication) frequencies from three study sites in East DRC

\begin{tabular}{llllll}
\hline Study site (Province) & $\begin{array}{l}\text { Homozygote CYP6P4- } \\
\text { I236M-ZZB-TE wild } \\
\text { type }\end{array}$ & $\begin{array}{l}\text { Double CYP6P4- } \\
\text { I236M-ZZB-TE } \\
\text { mutant }\end{array}$ & $\begin{array}{l}\text { Heterozygote } \\
\text { CYP6P4-I236M- } \\
\text { ZZB-TE-CYP6AA1 } \\
\text { duplication (triple } \\
\text { mutant) }\end{array}$ & $\begin{array}{l}\text { Homozygote CYP6P4- } \\
\text { I236M-ZZB-TE- } \\
\text { CYP6AA1 duplication } \\
\text { (triple mutant) }\end{array}$ & $\begin{array}{l}\text { CYP6P4-I236M-ZZB-TE- } \\
\text { CYP6AA1 duplication } \\
\text { (triple mutant) } \\
\text { frequency }\end{array}$ \\
\hline $\begin{array}{l}\text { Tchonka (Sud-Kivu) } \\
\text { Tushunguti (Sud-Kivu) }\end{array}$ & 0 & 1 & 4 & 33 & 0.76 \\
Kibali (Haut-Uélé) & 0 & 0 & 0 & 1 & 0.5 \\
\hline
\end{tabular}

mutant CYP6P4-I236M-ZZB-TE was detected in nine An. gambiae s.l. from Tchonka.

\section{Anopheles funestus s.l. metabolic mutation screening} Mosquito individuals morphologically identified as $A n$. funestus s.l. were screened for three mutations in metabolic genes (Table 6). L119F-GSTe2 was not detected in any individual tested (Table 6). CYP6P9a was present in $100 \%$ of $A n$. funestus s.l. tested (152/152); $67.8 \%$ (103/152) were homozygous and 32.2\% (49/152) were heterozygous (Table 6). In Tchonka CYP6P9a allele frequency was 0.82 , with significant deviations from HardyWeinberg equilibrium $\left(x^{2}=6.59 ; p=0.01\right)$; no evidence for ongoing selection was observed in Tushunguti (Table 6). CYP6P9b was present in 94.9\% of An. funestus s.l. screened (131/138); 70.2\% (92/131) were homozygous and 29.8\% (39/131) were heterozygous (Table 6). In Tushunguti CYP6P9b allele frequency was 0.65 , with significant deviations from Hardy-Weinberg equilibrium $\left(\chi^{2}=4.0 ; p=0.05\right)$; no evidence for ongoing selection was observed in Tchonka (Table 6). Presence of the CYP6P9b resistant allele was significantly associated with $P$. falciparum infection $\left(\chi^{2}=7.03, p=0.008\right)$, while presence of the CYP6P9a resistant allele was not $\left(\mathrm{X}^{2}=1.39, p=0.238\right)$.

\section{Discussion}

By comparison to neighbouring malaria-endemic countries, there is a considerable paucity of available molecular insecticide resistance data in the DRC. This study assessed the frequency of 11 resistance mutations among field populations of $A n$. gambiae s.l. and An. funestus s.l., to provide additional information on resistance mechanisms in the eastern DRC, and to critically evaluate the utility of these markers for prospective country-wide resistance monitoring.

Because the NMCP vector control strategy relies almost exclusively on universal coverage of ITNs, high levels of pyrethroid resistance and cross-resistance to DDT are widespread, with some evidence for increasing pyrethroid resistance intensity following distribution of ITNs in parts of Kinshasa province [14]. Unsurprisingly, the pyrethroid-associated L1014F- $k d r$ and L1014S- $k d r$ mutations in the voltage-gated sodium channel (VGSC) are present in $A n$. gambiae s.l. across the country and can be found in high frequencies in some locales [11, 14]. Prior to this study, molecular resistance monitoring had been undertaken in Kibali in 2011-2012, reporting a moderate prevalence of L1014S- $k d r(0.61)$ and lower levels of L1014F- $k d r(0.1)$ and L1014F/S-kdr (0.26) [12] (Additional file 1: Table S1). The L1014S- $k d r$ allele frequency of 0.78 in this dataset from 2017-2019 supports these previous surveys, with evidence for ongoing selection of this allele. One additional study has been performed in Tchonka from April-November, 2018 [11] indicating almost complete fixation of L1014F- $k d r(0.98)$, which was also consistent with this study's observations of slightly lower frequencies of this mutation (0.75), which may have risen over time under selection. The predictive association between L1014F- $k d r$ and L1014S- $k d r$ and resistance phenotype (i.e. survival or death following an insecticide bioassay or exposure to a vector control intervention) is not absolute [30], but both mutations 


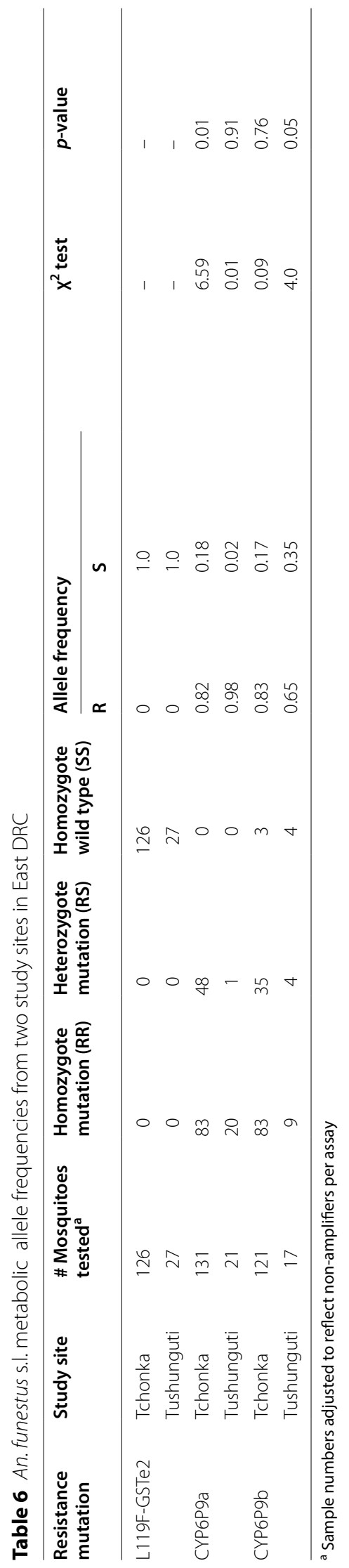


have been proposed to play a larger contributing role in resistance to type I (permethrin) versus type II (alphacypermethrin and deltamethrin) pyrethroids [31], which broadly aligns with observations of lower permethrin susceptibility, compared to deltamethrin or alpha-cypermethrin, in some local vector populations [10, 11, 14, 32]; it is also important to note that differences in discriminating concentrations of pyrethroids used for resistance monitoring and other coinciding resistance mechanisms may also explain some of these discrepancies [33]. This study also demonstrated a proportion of An. gambiae s.l. individuals with both L1014F- $k d r$ and L1014S-kdr mutations co-occurring in Sud-Kivu province. This phenomenon has also been observed in Kinshasa [14] and Nord-Ubangi provinces [10], as well as in other areas of East and West Africa [34, 35]. While the biological implications of harbouring both resistant alleles are unclear, it adds an additional complication to routine genotypic surveillance and supports the use of newly-developed single detection assays [10]. A second mutation in the VGSC, N1575Y, located downstream of L1014F- $k d r$, can have a synergistic effect on pyrethroid and DDT resistance $[24,36]$, but was not observed in any An. gambiae s.l. screened. It has only been reported once previously in the DRC, at very low frequencies in An. gambiae s.s. and Anopheles coluzzii from Nord-Ubangi [10]. The recent characterization of 20 additional non-synonymous nucleotide substitutions in the VGSC has revealed that the molecular basis of target-site pyrethroid resistance in malaria vectors may be more complex than previously thought [37]. This is of particular relevance in the DRC where high genetic diversity in $k d r$ haplotypes has been described, suggesting that these resistance alleles may have either originated in central Africa and spread across the continent or converged in the DRC and persisted without replacement [38].

In all three study sites, a non-synonymous substitution in CYP4J5 was identified at moderate levels (0.42-0.52), for the first time in the DRC. The point mutation used in this assay is in tight linkage disequilibrium (LD) with the L43F-CYP4J5 variant, which has previously been associated with resistance to lambda-cyhalothrin in An. gambiae s.s. from Uganda and to deltamethrin in Uganda and Kenya [26]. Furthermore, this mutation has been shown to be highly diagnostic of extreme pyrethroid resistance, with survivors of two hour deltamethrin exposure significantly more likely to have L43F-CYP4J5, compared to those killed within one hour [26]. L43F-CYP4J5 lies within the $2 \mathrm{La}+{ }^{\mathrm{a}}$ inversion in An. gambiae s.l., which has previously been correlated with aspects of vector bionomics and competence, including adaptation to aridity or humidity [39], biting and resting behaviour [40] and susceptibility to $P$. falciparum infection [41]. In this study, evidence for ongoing selection of this inversion was apparent in Tchonka, which may in part explain the deviations from Hardy-Weinberg equilibrium observed for L43F-CYP4J5 in this site, but not in Tushunguti or Kibali. Importantly, L43F-CYP4J5 may warrant further monitoring as a potential predictor of extreme pyrethroid resistance in the DRC.

This study also presents the first report of G119S-ace1 from all study sites at low frequencies (0.11-0.19), which did not appear to be under local selection at the time of sample collection. Duplication of the G119S-ace1 mutation can enhance resistance to organophosphates and carbamates [42], including pirimiphos-methyl which is widely used in IRS campaigns [43], by reducing sensitivity to the neurotransmitter acetylcholinesterase [44]. In these study sites, limited insecticide spraying operations have been conducted, except in Kibali in the gold mining region. It is difficult to infer the emergence of G119Sace1 in direct response to public health insecticides; rather this may have been selected under the pressure of widespread, unregulated agricultural pesticide use [45, 46]. Finally in An. gambiae s.l. the presence of a triple mutant haplotype (a non-synonymous SNP in CYP6P4, an upstream insertion of a partial Zanzibar-like TE and duplication of the CYP6AA1 gene), associated with high levels of deltamethrin resistance [27], was identified at high frequencies across these study sites and represents an additional promising diagnostic marker for future surveillance of pyrethroid resistance.

Previous studies in the DRC have reported overexpression of CYP6P9a and CYP6P9b in An. funestus s.l. as mechanisms of pyrethroid and DDT resistance in Kinshasa and Haut-Uélé provinces [12, 13]. The presence of cis-regulatory polymorphisms in CYP6P9a and CYP6P9b, which drive overexpression, have been correlated with reduced efficacy of deltamethrin ITNs [18, 19]. Using two DNA-based assays, moderate to high frequencies of both resistance alleles were identified, with potential evidence for ongoing selection of CYP6P9a in Tchonka and CYP6P9b in Tushunguti. For both An. gambiae s.l. and An. funestus s.l., the impact of some of these mutations on intervention effectiveness, coupled with recent data demonstrating partial restoration of pyrethroid susceptibility following PBO pre-exposure in bioassays $[8,10]$, improved killing of populations containing triple mutants with PBO-ITNs [27] and high mortality to the putative diagnostic doses of chlorfenapyr [47], strongly support targeted deployment of next-generation synergist- and dual-active ingredient ITNs to control pyrethroid-resistant vector populations in the DRC.

Consistent with other reports from the DRC, very high $P$. falciparum infection rates were detected, which were comparable between both An. gambiae s.l. and An. 
funestus s.l. across study sites (10.94-11.04\%); P. falciparum infection prevalence was twice as high for both species in Tchonka compared to Tushunguti. While this study used PCR to assess overall vector infection rate, comparably high sporozoite rates in An. gambiae s.l., measured by ELISA, have been previously described from nearby Kashuga, Nord-Kivu (13.9\%) [32]. While malaria transmission is known to be highly heterogeneous across the country, these observations of high Plasmodium infection levels in pyrethroid-resistant vector populations, which may be less responsive to standard ITNs, are of considerable concern.

\section{Conclusions}

Real-time tracking of insecticide resistance is currently limited by the lack of diagnostic markers of intervention efficacy and difficulties dissecting the relative contributions of different mechanisms to resistance phenotype, particularly those involved in metabolic resistance. This study screened the most up-to-date panel of DNA-based resistance markers for target site and metabolic resistance in An. gambiae s.l. and An. funestus s.l. populations from the eastern DRC, where resistance data is lacking. Several new candidate markers (L43F-CYP4J5, G119S-ace1, the triple mutant: CYP6P4-I236M-Zanzibar-like TE-CYP6AA1 duplication, CYP6P9a and CYP6P9b) were identified, which are diagnostic of resistance to major insecticide classes used for malaria vector control and/or reduced pyrethroid ITN efficacy, and warrant future, larger-scale monitoring in the DRC to inform vector control decisions by the NMCP.

\begin{abstract}
Abbreviations
Ace1: Acetylcholinesterase; ANC: Antenatal care; BP: Bbase pair; Cox-1: Cytochrome c oxidase subunit 1; CDC: Centers for Disease Control and Prevention; CNV: Copy number variant; CYP450: Cytochrome-dependent monooxygenase 450; DDT: Dichlorodiphenyltrichloroethane; DHS: Demographic and Health surveys; DRC: Democratic Republic of the Congo; EPI: Expanded programme on immunization; GST: Glutathione-s-transferase; IRB: Institutional review board; IRS: Indoor residual spraying; ITN: Insecticide-treated net; $K d r$ : Knock-down resistance; LD: Linkage disequilibrium; LNA: Locked-nucleic acid; LSHTM: London School of Hygiene and Tropical Medicine; NMCP: National Malaria Control Programme; NTC: No template control; OR: Odds ratio; PBO: Piperonyl butoxide; rdl: Resistance to dieldrin; SNP: Single-nucleotide polymorphism; TE: Transposable element; VGSC: Voltage-gated sodium channel.
\end{abstract}

\section{Supplementary Information}

The online version contains supplementary material available at https://doi. org/10.1186/s12936-021-04002-8.

Additional file 1: TableS1. Summary of all published insecticide resistance mechanism data from the DRC.

\section{Acknowledgements}

The authors would like to thank all mosquito collectors for their dedicated work. The authors would also like to thank Drs. David Weetman and Amy Lynd for their invaluable advice, interpreting the triple LNA PCR assays.

\section{Authors' contributions}

$J B$, TW and LAM designed the overall study and were responsible for data analysis and interpretation. JB, SND, CB, VB, MJ, MG, BZ, AD and JP contributed to study conception, led the entomology field activities and participated in data collection. CML, under the supervision of LAM, generated the molecular data and produced Fig. 1. DRC Map using QGIS Software. LAM drafted the manuscript, which was revised by co-authors. All authors read and approved the final manuscript.

\section{Funding}

The authors would like to thank multiple partners for their financial support. Médecins Sans Frontières funded the mosquito field collections. Molecular analysis was funded by a Sir Halley Stewart Trust grant, awarded to LAM and a Wellcome Trust/Royal Society Sir Henry Dale Fellowship awarded to TW (101285/Z/13/Z): https://wellcome.org and https://royalsociety.org.

\section{Availability of data and materials \\ Not applicable.}

\section{Declarations}

\section{Ethics approval and consent to participate}

The study protocol in Tushunguti and in Tchonka was reviewed and approved by the National Ethics Committee of Health in the Democratic Republic of the Congo (approval number CNES001/DPSK/111PM/2017). For Kibali the protocol was reviewed and approved by the scientific ethics committee of the Centre de Recherche en Sciences Naturelles of the Université Officielle de Bukavu.

\section{Consent for publication}

Not applicable.

\section{Competing interests}

The authors declare that they have no competing interests.

\section{Author details}

'Laboratoire d'Entomologie Médicale et Parasitologie, Centre de Recherche en Sciences Naturelles (CRSN/Lwiro), Sud-Kivu, Democratic Republic of the Congo. ${ }^{2}$ Department of Disease Control, Faculty of Infectious and Tropical Diseases, London School of Hygiene and Tropical Medicine, London, UK. ${ }^{3}$ Médecins Sans Frontières (MSF) OCBA, Barcelona, Spain. ${ }^{4}$ Université Officielle de Bukavu, Bukavu, Democratic Republic of the Congo. ${ }^{5}$ Kibali Gold Mine, Haut-Uele, Democratic Republic of the Congo. 'Université Nazi Boni (UNB), Bobo-Dioulasso, Burkina Faso. ${ }^{7}$ UMR MIVEGEC (IRD-CNRS - Université de Montpellier), 911 Avenue Agropolis, 34394 Montpellier, France. ${ }^{8}$ Institut de Recherche en Sciences de la Santé (IRSS)/Centre MURAZ, Bobo-Dioulasso, Burkina Faso.

Received: 14 October 2021 Accepted: 1 December 2021

Published online: 14 December 2021

\section{References}

1. WHO. World malaria report. Geneva: World Health Organization; 2020.

2. Programme National de Lutte contre le Paludisme. An epidemiological profile of malaria in the Democratic Republic of Congo. Kinshasa: Ministry of Health; 2014.

3. Ecole de Santé Publique de Kinshasa, République Démocratique du Congo. Evaluation des Prestations des Services de soins de Santé 2017-2018. Kinshasa; 2019.

4. Programme National de Lutte contre le Paludisme. Plan stratégiquenational de lutte contre le paludisme 2013-2015. Kinshasa; 2013.

5. U.S. President's Malaria Initiative. Democratic Republic of the Congo: malaria operational plan FY 2020. Kinshasa; 2020. 
6. The Net Mapping Project. http://netmappingproject.allianceformalariapr evention.com/. Accessed 30 Nov 2021

7. The DHS Program. Malaria indicator survey (MIS). https://dhsprogram. com/. Accessed 30 Nov 2021.

8. Wat'senga FT, Manzambi EZ, Lunkula A, Mulumbu R, Mampangulu T, Lobo $\mathrm{N}$, et al. Nationwide insecticide resistance status and biting behaviour of malaria vector species in the Democratic Republic of Congo. Malar J. 2018;17:129.

9. Matubi EM, Kaounga GI, Zanga J, Mbuku GB, Maniania JNK, Mulenda B, et al. Insecticide susceptibility of Anopheles gambiae s.l. and identification of some resistance mechanisms in Kwilu Province in the Democratic Republic of Congo. Pan Afr Med J. 2020;37:1-13.

10. Lynd A, Oruni A, van't Hof A, Morgan JC, Naego LB, Pipini D, et al. Insecticide resistance in Anopheles gambiae from the northern Democratic Republic of Congo, with extreme knockdown resistance (kdr) mutation frequencies revealed by a new diagnostic assay. Malar J. 2018;17:412.

11. N'do S, Bandibabone JB, Soma DD, Musaka BZ, Prudhomme J, Habamungu CC, et al. Insecticide resistance profiles in malaria vector populations from Sud-Kivu in the Democratic Republic of the Congo. Trans R Soc Trop Med Hyg. 2021;115:1339-44.

12. Nardini L, Hunt RH, Dahan-Moss YL, Christie N, Christian RN, Coetzee $\mathrm{M}$, et al. Malaria vectors in the Democratic Republic of the Congo: the mechanisms that confer insecticide resistance in Anopheles gambiae and Anopheles funestus. Malar J. 2017;16:448.

13. Riveron JM, Watsenga F, Irving H, Irish SR, Wondji CS. High Plasmodium infection rate and reduced bed net efficacy in multiple insecticide-resistant malaria vectors in Kinshasa, Democratic Republic of Congo. I Infect Dis. 2018;217:320-8.

14. Wat'senga FT, Agossa F, Manzambi EZ, Illombe G, Mapangulu T, Muyembe $T$, et al. Intensity of pyrethroid resistance in Anopheles gambiae before and after a mass distribution of insecticide-treated nets in Kinshasa and in 11 provinces of the Democratic Republic of Congo. Malar J. 2020;19:169.

15. Levitz L, Janko M, Mwandagalirwa K, Thwai KL, Likwela JL, Tshefu AK, et al. Effect of individual and community-level bed net usage on malaria prevalence among under-fives in the Democratic Republic of Congo. Malar J. 2018;17:39.

16. Consortium AgG. Genome variation and population structure among 1142 mosquitoes of the African malaria vector species Anopheles gambiae and Anopheles coluzzii. Genome Res. 2020;10:1533-46.

17. Consortium TAgG. Genetic diversity of the African malaria vector Anopheles gambiae. Nature. 2017;552:96-100.

18. Weedall GD, Mugenzi LMJ, Menze BD, Tchouakui M, Ibrahim SS, Amvongo-Adjia N, et al. A cytochrome P450 allele confers pyrethroid resistance on a major African malaria vector, reducing insecticide-treated bednet efficacy. Sci Transl Med. 2019;11:eaat7386.

19. Mugenzi LMJ, Menze BD, Tchouakui M, Wondji MJ, Irving H, Tchoupo $\mathrm{M}$, et al. Cis-regulatory CYP6P9b P450 variants associated with loss of insecticide-treated bed net efficacy against Anopheles funestus. Nat Commun. 2019;10:4652.

20. Gillies MT, De Meillon B. The Anophelinae of Africa south of the Sahara (Ethiopian Zoogeographical Region). Publ South African Institute for Medical Research. 1968;54:1-343.

21. Wilkins EE, Howell PI, Benedict MQ. IMP PCR primers detect single nucleotide polymorphisms for Anopheles gambiae species identification, Mopti and Savanna rDNA types, and resistance to dieldrin in Anopheles arabiensis. Malar J. 2006;5:125.

22. Koekemoer LL, Kamau L, Hunt RH, Coetzee M. A cocktail polymerase chain reaction assay to identify members of the Anopheles funestus (Diptera: Culicidae) group. Am J Trop Med Hyg. 2002;66:804-11.

23. Marie A, Boissiere A, Tchioffo MT, Poinsignon A, Awono-Ambene PH, Morlais I, et al. Evaluation of a real-time quantitative PCR to measure the wild Plasmodium falciparum infectivity rate in salivary glands of Anopheles gambiae. Malar J. 2013;12:224.

24. Jones CM, Liyanapathirana M, Agossa FR, Weetman D, Ranson H, Donnelly $\mathrm{MJ}$, et al. Footprints of positive selection associated with a mutation (N1575Y) in the voltage-gated sodium channel of Anopheles gambiae. Proc Natl Acad Sci USA. 2012;109:6614-9.

25. BEl Resources. Methods in Anopheles research. 4th ed. Atlanta: CDC; 2014.

26. Weetman D, Wilding CS, Neafsey DE, Muller P, Ochomo E, Isaacs AT, et al. Candidate-gene based GWAS identifies reproducible DNA markers for metabolic pyrethroid resistance from standing genetic variation in East African Anopheles gambiae. Sci Rep. 2018;8:2920.

27. Njoroge H, van't A, Oruni A, Pipini D, Nagi SC, Lynd A, et al. Identification of a rapidly-spreading triple mutant for high-level metabolic insecticide resistance in Anopheles gambiae provides a real-time molecular diagnostic for anti-malarial intervention deployment. bioRxiv. 2021.02.11.429702. https://doi.org/10.1101/2021.02.11.429702

28. Riveron JM, Yunta C, Ibrahim SS, Djouaka R, Irving H, Menze BD, et al. A single mutation in the GSTe2 gene allows tracking of metabolically based insecticide resistance in a major malaria vector. Genome Biol. 2014;15:R27.

29. Cansado-Utrilla C, Jeffries CL, Kristan M, Brugman VA, Heard P, Camara G, et al. An assessment of adult mosquito collection techniques for studying species abundance and diversity in Maferinyah, Guinea. Parasit Vectors. 2020;13:150.

30. Collins E, Vaselli NM, Sylla M, Beavogui AH, Orsborne J, Lawrence G, et al. The relationship between insecticide resistance, mosquito age and malaria prevalence in Anopheles gambiae s.l. from Guinea. Sci Rep. 2019;9:8846.

31. Reimer L, Fondjo E, Patchoke S, Diallo B, Lee Y, Ng A, et al. Relationship between kdr mutation and resistance to pyrethroid and DDT insecticides in natural populations of Anopheles gambiae. J Med Entomol. 2008:45:260-6.

32. Loonen JACM, Dery DB, Musaka BZ, Bandibabone JB, Bousema T, van Lenthe $\mathrm{M}$, et al. Identification of main malaria vectors and their insecticide resistance profile in internally displaced and indigenous communities in Eastern Democratic Republic of the Congo (DRC). Malar J. 2020;19:425.

33. Lissenden N, Kont MD, Essandoh J, Ismail HM, Churcher TS, Lambert B, et al. Review and meta-analysis of the evidence for choosing between specific pyrethroids for programmatic purposes. Insects. 2021;12:826.

34. Verhaeghen K, Van Bortel W, Roelants P, Backeljau T, Coosemans M. Detection of the East and West African kdr mutation in Anopheles gambiae and Anopheles arabiensis from Uganda using a new assay based on FRET/Melt curve analysis. Malar J. 2006;5:16.

35. Thiaw O, Doucoure S, Sougoufara S, Bouganali C, Konate L, Diagne N, et al. Investigating insecticide resistance and knock-down resistance (kdr) mutation in Dielmo, Senegal, an area under long lasting insecticidaltreated nets universal coverage for 10 years. Malar J. 2018;17:123.

36. Wang L, Nomura Y, Du Y, Liu N, Zhorov BS, Dong K. A mutation in the intracellular loop III/IV of mosquito sodium channel synergizes the effect of mutations in helix IIS6 on pyrethroid resistance. Mol Pharmacol. 2015:87:421-9.

37. Clarkson CS, Miles A, Harding NJ, O'Reilly AO, Weetman D, Kwiatkowski $D$, et al. The genetic architecture of target-site resistance to pyrethroid insecticides in the African malaria vectors Anopheles gambiae and Anopheles coluzzii. Mol Ecol. 2021;30:5303-17.

38. Lucas ER, Rockett KA, Lynd A, Essandoh J, Grisales N, Kemei B, et al. A high throughput multi-locus insecticide resistance marker panel for tracking resistance emergence and spread in Anopheles gambiae. Sci Rep. 2019;9:13335.

39. Fouet C, Gray E, Besansky NJ, Costantini C. Adaptation to aridity in the malaria mosquito Anopheles gambiae: chromosomal inversion polymorphism and body size influence resistance to desiccation. PLOS ONE. 2012; :e34841.

40. Coluzzi M, Sabatini A, Petrarca V, Di Deco MA. Behavioural divergences between mosquitoes with different inversion karyotypes in polymorphic populations of the Anopheles gambiae complex. Nature. 1977;266:832-3.

41. Riehle MM, Bukhari T, Gneme A, Guelbeogo WM, Coulibaly B, Fofana $A$, et al. The Anopheles gambiae $2 \mathrm{La}$ chromosome inversion is associated with susceptibility to Plasmodium falciparum in Africa. eLife. 2017;6:e25813.

42. Edi CV, Djogbenou L, Jenkins AM, Regna K, Muskavitch MAT, Poupardin $\mathrm{R}$, et al. CYP6 P450 enzymes and ACE-1 duplication produce extreme and multiple insecticide resistance in the malaria mosquito Anopheles gambiae. PLoS Genet. 2014;10:e1004236.

43. Grau-Bove X, Lucas E, Pipini D, Rippon E, van't Hof A, Constant E, et al. Resistance to pirimiphos-methyl in West African Anopheles is spreading via duplication and introgression of the Ace1 locus. PLoS Genet. 2021;17:e1009253. 
44. Bourguet D, Roig A, Toutant JP, Arpagaus M. Analysis of molecular forms and pharmacological properties of acetylcholinesterase in several mosquito species. Neurochem Int. 1997;31:65-72.

45. Orondo PW, Nyanjom SG, Atieli H, Githure J, Ondeto BM, Ochwedo KO, et al. Insecticide resistance status of Anopheles arabiensis in irrigated and non-irrigated areas in western Kenya. Parasit Vectors. 2021;14:335.

46. Chouaibou MS, Fodjo BK, Fokou G, Allassane OF, Koudou BG, David J-P, et al. Influence of the agrochemicals used for rice and vegetable cultivation on insecticide resistance in malaria vectors in southern Côte d'Ivoire. Malar J. 2016;15:426.

47. Oxborough RM, Seyoum A, Yihdego Y, Chabi J, Wat'senga F, Agossa FR, et al. Determination of the discriminating concentration of chlorfenapyr (pyrrole) and Anopheles gambiae sensu lato susceptibility testing in preparation for distribution of Interceptor ${ }^{\circledR} \mathrm{G} 2$ insecticide-treated nets. Malar J. 2021;20:316.

\section{Publisher's Note}

Springer Nature remains neutral with regard to jurisdictional claims in published maps and institutional affiliations.

- fast, convenient online submission

- thorough peer review by experienced researchers in your field

- rapid publication on acceptance

- support for research data, including large and complex data types

- gold Open Access which fosters wider collaboration and increased citations

- maximum visibility for your research: over 100M website views per year

At BMC, research is always in progress.

Learn more biomedcentral.com/submissions 